\title{
ANALISIS PENDAPATAN USAHATANI NILAM (Pogostemon cablin, Benth) DAN KONTRIBUSI TERHADAP PENDAPATAN KELUARGA PETANI DI KECAMATAN SEKERAK KABUPATEN ACEH TAMIANG
}

\author{
Ayu Sawalia ${ }^{1}$, Muhammad Jamil ${ }^{2}$ dan Silvia Anzitha ${ }^{2}$ \\ ${ }^{I}$ Mahasiswa Program Studi Agribisnis Fakultas Pertanian Universitas Samudra \\ ${ }^{2}$ Dosen Fakultas Pertanian Universitas Samudra \\ Penulis dapat dihubungi di email : milcareca@gmail.com atau Hp. 085261361567
}

\begin{abstract}
Abstrak
Penelitian ini bertujuan untuk menganalisis berapa besar pendapatan usahatani nilam dan kontribusinya terhadap pendapatan keluarga petani Di Kecamatan Sekerak Kabupaten Aceh Tamiang. Metode penelitian yang digunakan dalam penelitian ini adalah metode sampling jenuh (seluruhnya). Penentuan petani sampel dari masing masing desa sampel dilakukan secara acak sederhana (Simple Random Sampling), dengan menetapkan besarnya sampel yang akan diambil yaitu $45 \%$ untuk setiap desa sampel. Adapun desa-desa tersebut adalah Desa Bandar Mahligai, Pantai Tinja, dan Desa Sekerak Kiri.

Dari hasil penelitian menunjukan bahwa rata-rata karakteristik petani sampel yaitu umur 41 tahun, pendidikan 11 tahun, pengalaman 11 tahun, dan jumlah tanggungan keluarga 5 orang, dengan rata-rata luas lahan usahatani nilam 0,35 hektar dengan rata-rata biaya produksi yaitu Rp. 5.923.501/Tahun dan rata-rata penerimaan kotor atau nilai produksi yaituRp. 38.062.800/Tahun, ratarata pendapatan bersih yaitu Rp.32.139.299/Tahun dengan rata-rata pendapatan diluar usahatani nilam yaituRp. 12.104.000/Tahun dengan total pendapatan keluarga petani yaituRp.44.243.299/Tahun.

Rata-Rata kontribusi pendapatan usahatani nilam di Kecamatan Sekerak Kabupaten Aceh Tamiang terhadap pendapatan keluarga petani ialah sebesar 72,13\%. Dapat disimpulkan bahwa kontribusi usahatani nilam terhadap pendapatan keluarga petani lebih besar dari $50 \%$ atau $>50 \%$ dikatagorikan berkontribusi tinggi.
\end{abstract}

\section{Kata Kunci: Penerimaan, Biaya dan Pendapatan, Kontribusi, Pendapatan Keluarga Petani}

\section{PENDAHULUAN \\ Latar Belakang}

Pembangunan pertanian merupakan bagian dari pembangunan ekonomi nasional yang bertujuan untuk meningkatkan kesejahteraan rakyat terutama kesejahteraan petani yang sebagian besar hidupnya di pedesaan. Salah satu bentuk upaya yang dilakukan pemerintah sekarang ini adalah dengan melakukan peninjauan kembali atau melakukan reformasi dari cara lama pembangunan pertanian seperti sentralistik, mengutamakan peran langsung pemerintah, orientasi peningkatan produksi, tanpa mengabaikan kelestarian lingkungan dan terlalu protektif ke cara baru (paradigma, budidaya baru).

Salah satu produk olahan komoditi perkebunan yang menjadi andalan ekspor adalah minyak atsiri. Minyak atsiri dihasilkan dari proses pengolahan secara penyulingan atau ekstraksi dari tanaman atsiri. Kegunaannya adalah sebagai bahan baku industri produk kosmetik, parfum dan farmasi karena minyak atsiri memiliki sifat pengikat (fiksatif) sehingga bau wangi pada parfum, kosmetik maupun sabun dapat bertahan lebih lama.

Tanaman nilam merupakan kelompok tanaman penghasil minyak atsiri Daun kering tanaman ini disuling untuk mendapatkan minyak nilam (patchouli oil) yang banyak digunakan dalam berbagai kegiatan industri. seperti kebutuhan industri makanan (di antaranya untuk essence atau penambah rasa), kebutuhan farmasi (untuk pembuatan anti radang, antifungi, anti serangga, afrodisiak, anti inflamasi, antidepresi, antiflogistik, serta dekongestan), kebutuhan aroma terapi, bahan baku compound dan pengawetan barang, sebagai bahan pengendali penerbang (eteris) serta berbagai kebutuhan industri lainnya. Minyak nilam dari Indonesia merupakan minyak nilam terbaik di dunia dan sampai saat ini belum bisa dibuat tiruannya (sintetisnya), sehingga harga minyak nilam cenderung tinggi (Kardinan, 2005:42). 
Usahatani nilam diharapkan dapat terus memberikan kontribusi yang tinggi terhadap pendapatan keluarga petani untuk bisa memenuhi kebutuhan hidup keluarganya. Potensi dan prospek pengembangan usaha minyak nilam cukup besar tetapi usaha ini memiliki berbagai kendala dikarenakan produksi pertanian sangat tergantung pada alam sebagai sumber daya utamanya, sehingga pendapatan yang diperoleh tidak stabil. Petani nilam tidak hanya terfokus pada usahatani nilam saja tetapi juga terfokus pada usaha lainya untuk dapat memenuhi kebutuhan hidup keluarganya sehari-hari.

\section{Identifikasi Masalah}

Berapa besar pendapatan usaha minyak nilam dan kontribusinya terhadap pendapatan keluarga petani di Kecamatan Sekerak Kabupaten Aceh Tamiang ?

\section{Tujuan Penelitian}

Untuk menganalisis berapa besar pendapatan usaha minyak nilam dan kontribusinya terhadap pendapatan keluarga petani di daerah penelitian.

\section{Hipotesis Penelitian}

Usaha minyak nilam menguntungkan bagi petani dan memberi kontribusi tinggi terhadap total pendapatan keluarga petani di Kecamatan Sekerak Kabupaten Aceh Tamiang.

\section{METODOLOGI PENELITIAN Lokasi, Objek dan Ruang Lingkup dan Waktu Penelitian}

Penelitian ini dilaksanakan di Kecamatan Sekerak Kabupaten Aceh Tamiang dengan menggunakan metode survey. Metode survey adalah penelitian yang diadakan untuk memperoleh fakta dari gejala-gejala yang ada dan mencari keterangan-keterangan secara faktual tentang institusi sosial, ekonomi atau politik dari suatu daerah (Nazir, 2005:56). Objek dalam penelitian ini hanya dibatasi pada petani yang mengusahakan tanaman nilam yang ada di di Kecamatan Sekerak Kabupaten Aceh Tamiang.

Ruang lingkup penelitian ini meliputi biaya produksi, produksi, pendapatan usaha minyak nilam dan kontribusinya terhadap pendapatan rumah tangga petani di Kecamatan Sekerak Kabupaten Aceh Tamiang. Waktu Penelitian ini dilaksanakan pada bulan Agustus sampai September 2017.

\section{Teknik Penentuan Sampel}

Kecamatan Sekerak Kabupaten Aceh Tamiang terdiri dari 14 Desa, dari 14 desa tersebut hanya terdapat 3 desa yang terdapat usahatani nilam, dari ke 3 desa tersebut seluruhnya dijadikan desa sampel. Penentuan desa sampel dilakukan dengan menggunakan teknik sampling jenuh. Menurut Sugiyono (2008:122) "Sampling jenuh adalah teknik penentuan sampel bila semua populasi digunakan sebagai sampel. Desa tersebut yaitu Desa Bandar Mahligai, Desa Pantai Tinjau dan Desa Sekerak Kiri.

Metode pengambilan sampel yaitu dengan Sampel Acak Sederhana (Simple Random Sampling). Besarnya sampel yang diambil adalah $45 \%$ untuk setiap desa sampel. Adapun jumlah populasi dan petani sampel masing masing desa adalah seperti terlihat pada tabel 2 berikut ini :

Tabel 2. Jumlah Populasi dan Sampel Petani Nilam di Daerah Penelitian, 2017.

\begin{tabular}{|l|l|c|c|}
\hline No & \multicolumn{1}{|c|}{ Desa Sampel } & $\begin{array}{c}\text { Jumlah Populasi } \\
\text { (Orang) }\end{array}$ & $\begin{array}{c}\text { Jumlah Sampel } \\
\text { (Orang) }\end{array}$ \\
\hline 1. & Bandar Mahligai & 20 & 9 \\
2. & Pantai Tinjau & 25 & 11 \\
3. & Sekerak Kiri & 22 & 10 \\
\hline \multicolumn{1}{|c|}{ Jumlah } & 67 & 30 \\
\hline
\end{tabular}

Sumber : Data Primer, 2017 (diolah).

Berdasarkan tabel 2 diatas dapat dilihat bahwa jumlah populasi adalah sebanyak 67 orang. Jumlah sampel pada masing-masing desa yaitu, Bandar Mahligai 9 orang, Pantai Tinjau 11 orang, Sekerak Kiri 10 orang, sehingga jumlah sampel keseluruhan yaitu 30 orang. 
Metode Analisis dan Pengujian Hipotesis

Metode analisis yang digunakan untuk melihat besarnya pendapatan usaha minyak nilam dan kontribusinya terhadap pendapatan keluarga petani dapat digunakan rumus sebagai berikut :

1. Analisis Biaya Produksi, dihitung dengan rumus (Suryani, 2014:99) :

$\mathrm{TC}=\mathrm{FC}+\mathrm{VC}$

Dimana:

$\mathrm{TC}=$ Total Cos (total biaya) $(\mathrm{Rp} / \mathrm{Ha} / \mathrm{Thn})$

$\mathrm{FC}=$ Fixed Cost (biaya tetap)

$(\mathrm{Rp} / \mathrm{Ha} / \mathrm{Thn})$

$\mathrm{VC}=$ Variable Cost (biaya tidak tetap) ( $\mathrm{Rp} / \mathrm{Ha} / \mathrm{Thn})$

2. Pendapatan Kotor Usaha minyak nilam dihitung dengan rumus (Rahim dan Diah, 2007:57) :

$\mathrm{TR}=\mathrm{Y} \times \mathrm{Py}$

Dimana:

$\mathrm{TR}=$ Pendapatan Kotor $(\mathrm{Rp} / \mathrm{Ha} / \mathrm{Thn})$

$\mathrm{Y}=$ Produksi Nilam $(\mathrm{Rp} / \mathrm{Kg})$

Py = Harga Nilam $(\mathrm{Rp} / \mathrm{Kg})$

3. Pendapatan Bersih Usaha Minyak Nilam dihitung dengan rumus (Rahim dan Diah, 2007:60):

$\mathrm{Pd}=\mathrm{TR}-\mathrm{TC}$

Dimana:

$\mathrm{Pd}=$ Pendapatan Bersih $(\mathrm{Rp} / \mathrm{Ha} / \mathrm{Thn})$

$\mathrm{TR}=$ Pendapatan Kotor $(\mathrm{Rp} / \mathrm{Ha} / \mathrm{Thn})$

$\mathrm{TC}=$ Total Biaya $(\mathrm{Rp} / \mathrm{Ha} / \mathrm{Thn})$

Dengan kriteria keputusan :

a. Jika pendapatan usaha minyak nilam positif $(\mathrm{Pd}>0)$ maka usahatani nilam di Kecamatan Sekerak menguntungkan.

b. Jika pendapatan usaha minyak nilam negatif $(\mathrm{Pd}<0)$ maka usahatani nilam di
Kecamatan Sekerak tidak menguntungkan.

4. Kontribusi Pendapatan Usaha minyak Nilam Terhadap Pendapatan Keluarga Petani di Kecamatan Sekerak

$\mathrm{Kp}=\frac{\mathrm{X}}{\mathrm{Y}} \times 100 \%$

Dimana :

Kp $=$ Kontribusi Pendapatan Usaha Minyak Nilam Terhadap Pendapatan

Keluarga Petani (\%)

$\mathrm{X}=$ Pendapatan Usaha Minyak Nilam $(\mathrm{Rp} / \mathrm{Ha} / \mathrm{MT})$

$\mathrm{Y}=$ Pendapatan Keluarga Petani (Rp)

Dengan kriteria keputusan ;

1. Jika kontribusi usaha minyak nilam < $30 \%$ pendapatan keluarga petani, dikatagorikan kontribusinya rendah

2. Jika kontribusi usaha minyak nilam berkisar antara 30 - 50\% pendapatan keluarga petani dikatagorikan kontribusinya sedang.

3. Jika kontribusi usaha minyak nilam berkisar antara > 50\% pendapatan keluarga petani dikatagorikan kontribusinya tinggi (Salbiah, 2007 dalam Aminah, 2016:21).

\section{HASIL DAN PEMBAHASAN \\ Karakteristik Petani}

Beberapa aspek yang mempengaruhi keterampilan petani dalam mengelola usahataninya adalah: umur, pendidikan, pengalaman bertani, dan jumlah anggota keluarga. Karakteristik petani nilam di Kecamatan Sekerak Kabupaten Aceh Tamiang tahun 2017 disajikan pada tabel 6 berikut:

Tabel 6. Rata-Rata Karakteristik Petani Sampel di Kecamatan Sekerak, 2017.

\begin{tabular}{|l|l|r|r|r|r|}
\hline No & \multicolumn{1}{|c|}{ Nama Desa } & $\begin{array}{c}\text { Umur } \\
\text { (Tahun) }\end{array}$ & $\begin{array}{c}\text { Pendidikan } \\
\text { (Tahun) }\end{array}$ & $\begin{array}{c}\text { Pengalaman } \\
\text { Berusahatani } \\
\text { (Tahun) }\end{array}$ & $\begin{array}{c}\text { Tanggungan } \\
\text { (Orang) }\end{array}$ \\
\hline 1. & Bandar Mahligai & 41 & 11 & 11 & 5 \\
2. & Pantai Tinjau & 41 & 10 & 11 & 5 \\
3. & Sekerak Kiri & 42 & 10 & 11 & 4 \\
\hline
\end{tabular}

Sumber : Lampiran 2

Data tabel 6 menunjukkan bahwa rata-rata umur petani nilam di Kecamatan Sekerak Kabupaten Aceh Tamiang adalah 41 tahun.Umur petani termasuk dalam usia produktif. Tingkat pendidikan rata-rata petani nilam di Kecamatan Sekerak KabupatenAceh Tamiang adalah 11 tahun atau setingkat kelas
II SMA. Hal ini menunjukkan bahwa petani nilam di Kecamatan Sekerak ini mempunyai pendidikan yang tingkatan tinggi. Rata-Rata petani nilam di Kecamatan Sekerak Kabupaten Aceh Tamiang telah berpengalaman selama 11 tahun. Pengalaman bertani berpengaruh terhadap kematangan petani dalam mengelola 
suatu usahatani, sehingga akan lebih meningkatkan kemampuannya dalam menguasai dan mengembangkan teknologi pertanian. Jumlah rata-rata anggota keluarga petani nilam di Kecamatan Sekerak KabupatenAceh Tamiang adalah 5 jiwa per kepala keluarga.

\section{Luas Lahan Garapan}

Besarnya penguasaan lahan pertanian sangat mempengaruhi pendapatan pertanian. RataRata luas lahan pertanian nilam di Kecamatan Sekerak Kabupaten Aceh Tamiang dapat dilihat dalam tabel 7 berikut ini:

Tabel 7. Rata-Rata Luas Lahan Garapan Usahatani Nilam Petani Sampel Kecamatan Sekerak, 2017.

\begin{tabular}{|l|l|c|}
\hline No & \multicolumn{1}{|c|}{ Nama Desa } & Luas Lahan $(\mathrm{Ha})$ \\
\hline 1. & Bandar Mahligai & 0,39 \\
2. & Pantai Tinjau & 0,34 \\
3. & Sekerak Kiri & 0,31 \\
\hline \multicolumn{2}{|c|}{ Rata-Rata } & 0,35 \\
\hline
\end{tabular}

Sumber : Lampiran 3

Tabel 7 di atas dapat dilihat bahwa rata-rata luas lahan usahatani yang dikelola oleh petani sampel adalah sebesar 0,35 hektar, dimana luas lahan yang terbesar terdapat pada Desa Bandar Mahligai sebesar 0,39 hektar dan luas lahan terkecil terdapat pada Desa Sekerak Kiri yaitu sebesar 0,31 hektar.

\section{Penggunaan Tenaga Kerja}

Tabel 8. Rata-Rata Penggunaan Tenaga Kerja Pada Usahatani Nilam di Kecamatan Sekerak, 2017.

\begin{tabular}{|c|c|c|c|c|}
\hline \multirow[b]{2}{*}{ No } & \multirow[b]{2}{*}{ Nama Desa } & \multicolumn{2}{|c|}{ Penggunaan Tenaga Kerja } & \multirow[b]{2}{*}{$\begin{array}{l}\text { Total HKP/ } \\
\text { Tahun }\end{array}$} \\
\hline & & $\begin{array}{c}\text { DK } \\
\text { (HKP/Tahun) }\end{array}$ & $\begin{array}{c}\text { LK } \\
\text { (HKP/Tahun) }\end{array}$ & \\
\hline 1. & Bandar Mahligai & 75,48 & 51,43 & 126,96 \\
\hline 2. & Pantai Tinjau & 84,85 & 24,97 & 109,82 \\
\hline 3. & Sekerak Kiri & 85,60 & 21,93 & 107,53 \\
\hline & Rata-Rata & 82,29 & 31,91 & 114,20 \\
\hline
\end{tabular}

\section{Sumber : Lampiran 4}

Data tabel 8 dapat dilihat rata-rata penggunaan tenaga kerja pada usahatani nilam adalah sebesar 114,20 HKP/Tahun. Rata-Rata penggunaan tenaga kerja tertinggi di Desa Bandar Mahligai sebesar 126,96 HKP/Tahun dan terendah di Desa Sekerak Kiri sebesar 107,53 HKP/Tahun.

\section{Biaya Produksi}

Biaya produksi dari usahatani nilam adalah biaya yangdikeluarkan pada saat pelaksanaan

Tabel 9. Rata-Rata Penggunaan Biaya Tetap Pada Usahatani Nilam di Kecamatan Sekerak, 2017.

\begin{tabular}{|c|c|c|c|c|}
\hline \multirow[b]{2}{*}{ No } & \multirow[b]{2}{*}{ Nama Desa } & \multicolumn{2}{|c|}{ Biaya Tetap } & \multirow{2}{*}{$\begin{array}{c}\text { Jumlah } \\
\text { (Rp/Tahun) }\end{array}$} \\
\hline & & $\begin{array}{l}\text { Penyusutan } \\
\text { (Rp/Tahun) }\end{array}$ & $\begin{array}{c}\text { Sewa Lahan } \\
\text { (Rp/Tahun) }\end{array}$ & \\
\hline 1. & Bandar Mahligai & 177.278 & 785.556 & 962.834 \\
\hline 2. & Pantai Tinjau & 159.188 & 671.818 & 831.006 \\
\hline 3. & Sekerak Kiri & 150.847 & 620.000 & 770.847 \\
\hline & Rata-Rata & 161.835 & 688.667 & 850.501 \\
\hline
\end{tabular}

Sumber : Lampiran 6
Tenaga kerja dalam Usahatani nilam di daerah penelitian diperlukan untuk mengerjakan berbagai kegiatan seperti pemeliharaan, pemanenan, pengangkutan, pengeringan, dalam menghitung besarnya pencurahan tenaga kerja yang diserap untuk setiap fase kegiatan, seluruhnya dikonversikan ke dalam Hari Kerja Pria (HKP). Secara rinci penggunaan tenaga kerja pada usahatani nilam dapat dilihat pada tabel 8 berikut : usahatani nilam dilakukan. Biaya produksi terbagi atas 2 jenis, yaitu biaya tetap (fixed cost) dan biaya variabel (variabel cost). Biaya tetap terdiri dari biaya sewa lahan dan biaya penyusutan alat yang dipergunakan untuk diperhitungkan baik dibayar tunai maupun tidak tunai. Adapun besar biaya tetapyang digunakan dalam usahatani nilam dapat dilihat dalam tabel 9 berikut: 
Data tabel 9 menunjukan bahwa ratarata pengunaan biaya tetap usahatani nilam di Kecamatan Sekerak yaitu sebesar Rp. 850.501/ Tahun. Rata-rata penggunaan biaya tetap tertinggi di Desa Bandar Mahligai sebesar
Rp.962.834/Tahun dan terendah di Desa Sekerak Kiri sebesar 770.847/Tahun.

Untuk penggunaan biaya variabel secara keseluruhan yang terdiri dari biaya pembelian pupuk, pestisida dan biaya tenaga kerja dapat dilihat pada tabel 10 berikut :

Tabel 10. Rata-Rata Penggunaan Biaya Variabel Pada Usahatani Nilam di Kecamatan Sekerak, 2017.

\begin{tabular}{|c|c|c|c|c|c|}
\hline \multirow[b]{2}{*}{ No } & \multirow[b]{2}{*}{ Nama Desa } & \multicolumn{3}{|c|}{ Biaya Variabel } & \multirow[b]{2}{*}{$\begin{array}{c}\text { Jumlah } \\
\text { (Rp/Tahun) }\end{array}$} \\
\hline & & $\begin{array}{c}\text { Pupuk } \\
\text { (Rp/Tahun) }\end{array}$ & $\begin{array}{l}\text { Pestisida } \\
\text { (Rp/Tahun) }\end{array}$ & $\begin{array}{c}\text { Tenaga Kerja } \\
\text { (Rp/Tahun) }\end{array}$ & \\
\hline 1. & Bandar Mahligai & 713.333 & 933.333 & 3.808 .889 & 5.455 .556 \\
\hline 2. & Pantai Tinjau & 703.636 & 968.182 & 3.294 .545 & 4.966 .364 \\
\hline 3. & Sekerak Kiri & 671.000 & 949.000 & 3.226 .000 & 4.846 .000 \\
\hline & Rata-Rata & 695.667 & 951.333 & 3.426 .000 & 5.073 .000 \\
\hline
\end{tabular}

Sumber : Lampiran 6.

Tabel 10 menunjukan bahwa rata-rata penggunaan biaya variabel usahatani nilam di Kecamatan Sekerak yaitu sebesar Rp. 5.073.000/ Tahun. Rata-Rata penggunaan biaya variabel tertinggi yaitu di Desa Bandar Mahligai sebesar Rp.5.455.556/ Tahun dan

terendah di Desa Sekerak Kiri sebesar Rp.4.846.000/Tahun.

Total biaya produksi pada usahatani nilam di daerah penelitian adalah total biaya dari biaya tetap ditambah dengan biaya variabel. Untuk melihat total biaya produksi dapat dilihat pada tabel 11 berikut ini:

Tabel 11. Rata-rata Total Biaya Produksi Pada Usahatani Nilam di Kecamatan Sekerak, 2017.

\begin{tabular}{|l|l|r|}
\hline No & \multicolumn{1}{|c|}{ Nama Desa } & Biaya Produksi (Rp/Tahun) \\
\hline 1. & Bandar Mahligai & 6.418 .389 \\
2. & Pantai Tinjau & 5.797 .370 \\
3. & Sekerak Kiri & 5.616 .847 \\
\hline \multicolumn{2}{|c|}{ Rata-Rata } & 5.923 .501 \\
\hline
\end{tabular}

Sumber : Lampiran 7.

Tabel 11 dapat diketahui bahwa ratarata total biaya $(T C)$ yang dikeluarkan setiap petani dalam berusahatani nilam di Kecamatan Sekerak pada tahun 2017 adalah sebesar Rp. 5.923.501/Tahun. Rata-Rata penggunaan biaya produksi tertinggi berada di Desa Bandar Mahligai sebesar Rp.6.418.389/ Tahun, sedangkan biaya produksi terendah berada di Desa Sekerak Kiri sebesar Rp.

\section{Produksi}

Produksi yang dimaksud pada penelitian ini adalah hasil fisik yang diperoleh dari usahatani nilam. Produksi yang dihasilkan dalam bentuk ranting dan daun nilam yang telah dikeringkan dan kemudian disuling untuk mendapatkan minyak nilam yang akan dijual kepada agen di daerah penelitian:

\subsubsection{7/Tahun.}

Tabel 12. Rata-Rata Produksi MinyakNilam di Kecamatan Sekerak, 2017.

\begin{tabular}{|l|l|c|}
\hline No & \multicolumn{1}{|c|}{ Nama Desa } & Produksi $(\mathrm{Kg} / \mathrm{Tahun})$ \\
\hline 1. & Bandar Mahligai & 118,91 \\
2. & Pantai Tinjau & 103,02 \\
3. & Sekkerak Kiri & 96,85 \\
\hline \multicolumn{2}{|c|}{ Rata-rata } & 105,73 \\
\hline
\end{tabular}

Sumber: Lampiran 8.

Tabel 12 dapat dilihat bahwa rata-rata produksi minyak nilam dari usahatani nilam di Kecamatan Sekerak yaitu sebesar $105,73 \mathrm{Kg} /$ tahun. Rata-Rata produksi tertinggi berada di Desa Bandar Mahligai yaitu sebesar 118,91 
$\mathrm{Kg} / \mathrm{tahun}$ dan terendah berada di Desa

Sekerak Kiri sebesar 96,85 Kg/tahun.

\section{Nilai Produksi/Penerimaan Usahatani}

Nilam

Penerimaan yang diperoleh dari usahatani di

Kecamatan Sekerak adalah hasil perkalian antara produksi minyak nilam dalam satuan kilogram dengan harga penjualan yang berlaku di Kecamatan Sekerak.Pada umumnya petani menjual minyak nilam ke agen yang sekaligus menjadi tempat penyulingan daun nilam kering dengan harga Rp. 360.000 per kilogram. Besarnya penerimaan rata-rata per tahun pada usahatani nilam dapat dilihat pada tabel 13 berikut;

Tabel 13.Penerimaan Rata-Rata Usahatani Nilam di Kecamatan Sekerak, 2017.

\begin{tabular}{|l|l|r|}
\hline No & \multicolumn{1}{|c|}{ Nama Desa } & Pendapatan Kotor (Rp/Tahun) \\
\hline 1. & Bandar Mahligai & 42.808 .000 \\
2. & Pantai Tinjau & 37.086 .545 \\
3. & Sekerak Kiri & 34.866 .000 \\
\hline \multicolumn{2}{|c|}{ Rata-Rata } & 38.062 .800 \\
\hline
\end{tabular}

Sumber: Lampiran 8.

Tabel 13 dapat dilihat bahwa rata-rata penerimaan usahatani nilam di Kecamatan Sekerak adalah sebesar Rp.38.062.800/Tahun. Rata-Rata nilai produksi tertinggi berada di Desa Bandar Mahligai sebesar Rp. 42.808.000/ Tahun, sedangkan Rata-rata nilai produksi terendah berada di Desa Sekerak Kiri sebesar Rp. 34.866.000/Tahun.

Pendapatan Bersih Usahatani Nilam
Pendapatan usahatani nilam adalah pendapatan yang diperoleh responden dari usahatani nilam per tahun dan dinyatakan dalam rupiah. Pendapatan ini merupakan pendapatan bersih usahatani nilam yang berasal dari penerimaan hasil penjualan hasil produksi dikurangi dengan biaya produksi selama satu tahun dalam satuan rupiah. Pendapatan bersih dari usahatani nilam dapat dilihat dalam tabel 14 berikut ini:

Tabel 14. Rata-Rata Pendapatan Bersih Usahatani Nilam di Kecamatan Sekerak, 2017.

\begin{tabular}{|l|l|r|}
\hline No & \multicolumn{1}{|c|}{ Nama Desa } & Pendapatan Bersih (Rp/Tahun) \\
\hline 1. & Bandar Mahligai & 36.389 .611 \\
2. & Pantai Tinjau & 31.289 .176 \\
3. & Sekerak Kiri & 29.249 .153 \\
\hline \multicolumn{2}{|c|}{ Rata-Rata } & 32.139 .299 \\
\hline
\end{tabular}

Sumber : Lampiran 8.

Data tabel 14 dapat dilihat bahwa ratarata pendapatan bersih usahatani nilam di Kecamatan Sekerak yaitu sebesar Rp.32.139.299/ Tahun. Rata-Rata pendapatan bersih tertinggi berada di Desa Bandar Mahligai yaitu sebesar Rp. 36.389.611/Tahun dan terendah berada di Desa Sekerak Kiri sebesar Rp.29.249.153/Tahun.

Tabel 15. Rata-Rata Pendapatan petani di Luar Usaha Minyak Nilam di Kecamatan Sekerak, 2017.

\begin{tabular}{|l|l|r|}
\hline No & \multicolumn{1}{|c|}{ Nama Desa } & $\begin{array}{c}\text { Pendapatan Petani di Luar Usahatani } \\
\text { Nilam (Rp/Tahun) }\end{array}$ \\
\hline 1. & Bandar Mahligai & 11.784 .444 \\
2. & Pantai Tinjau & 13.098 .182 \\
3. & Sekerak Kiri & 11.298 .000 \\
\hline \multicolumn{2}{|c|}{ Rata-Rata } & 12.104 .000 \\
\hline
\end{tabular}

Sumber: Lampiran 9.

Data tabel 15 menunjukkan bahwa rata-rata pendapatan di luar usahatani nilam sebesar

\section{Pendapatan Petani di Luar Usahatani Nilam \\ Jumlah rata-rata pendapatan petani di luar usahatani nilamdapat dilihat pada tabel 15 berikut ini :}


Rp. 13.098.182/ Tahun, sedangkan pendapatan di luar usahatani nilam terendah terdapat di Desa Sekerak Kiri yaitu Rp. 11.298.000/Tahun.

\section{Pendapatan Total Keluarga Petani}

Tabel 16. Rata-Rata Pendapatan Total Keluarga Petani di Kecamatan Sekerak, 2017.

\begin{tabular}{|l|l|c|c|r|}
\hline No & \multicolumn{1}{|c|}{ Nama Desa } & $\begin{array}{c}\text { Pendapatan } \\
\text { Usahatani Nilam } \\
\text { (Rp/Tahun) }\end{array}$ & $\begin{array}{c}\text { Pendapatan diluar } \\
\text { Usahatani Nilam } \\
\text { (Rp/Tahun) }\end{array}$ & $\begin{array}{c}\text { Pendapatan } \\
\text { Total } \\
\text { (Rp/Tahun) }\end{array}$ \\
\hline 1. & Bandar Mahligai & 36.389 .611 & 11.784 .444 & 48.174 .055 \\
2. & Pantai Tinjau & 31.289 .176 & 13.098 .182 & 44.387 .358 \\
3. & Sekerak Kiri & 29.249 .153 & 11.298 .000 & 40.547 .154 \\
\hline \multicolumn{2}{|r|}{ Rata-Rata } & 32.139 .299 & 12.104 .000 & 44.243 .299 \\
\hline
\end{tabular}

Sumber: Lampiran 9.

Data pada tabel 16 menunjukkan bahwa rata-rata pendapatan total keluarga petani dilokasi penelitian adalah sebasar Rp.44.243.299/Tahun. Rata-Rata pendapatan total keluarga petani tertinggi terdapat di Desa Bandar Mahligai yaitu Rp.48.174.055/ Tahun, sedangkan pendapatan total keluarga petani terendah terdapat di Desa Sekerak Kiri yaitu Rp.40.547.154/Tahun.

\section{Kontribusi Pendapatan Usaha Minyak Nilam Terhadap Total Pendapatan Keluarga Petani}

Besarnya kontribusi pendapatan usahatani nilam yang diperoleh petani sampel akan diketahui dari nilai persentase terhadap pendapatan keluarga petani sampel tersebut. Besarnya kontribusi pendapatan usahatani nilam di Kecamatan Sekerak dapat dilihat pada tabel 17 berikut ini :

Tabel 17. Rata-Rata Kontribusi Pendapatan Usahatani Nilam Terhadap Pendapatan Keluarga Petani di Kecamatan Sekerak,2017.

\begin{tabular}{|l|l|c|c|r|}
\hline No & \multicolumn{1}{|c|}{ Nama Desa } & $\begin{array}{c}\text { Pendapatan } \\
\text { Usahatani Nilam } \\
\text { (Rp/Tahun) }\end{array}$ & $\begin{array}{c}\text { Pendapatan Total } \\
\text { Keluarga Petani } \\
\text { (Rp/Tahun) }\end{array}$ & $\begin{array}{c}\text { Kontribusi } \\
(\%)\end{array}$ \\
\hline 1. & Bandar Mahligai & 36.389 .611 & 48.174 .055 & 74,78 \\
2. & Pantai Tinjau & 31.289 .176 & 44.387 .358 & 70,03 \\
3. & Sekerak Kiri & 29.249 .153 & 40.547 .154 & 72,04 \\
\hline \multicolumn{2}{|c|}{ Rata-Rata } & 32.139 .299 & 44.243 .299 & 72,13 \\
\hline
\end{tabular}

Sumber: Lampiran 9.

Data tabel 17 menunjukkan bahwa rata-rata kontribusi pendapatan usahatani nilam memberikan kontribusi dengan kategori tinggi yakni sebesar $72,13 \%$ terhadap pendapatan keluarga petani di lokasi penelitian. Rata-rata kontribusi pendapatan tertinggi terdapat di desa Bandar Mahligai yaitu 74,78\% setiap tahunnya, sedangkan kontribusi pendapatan usahatani nilam terendah terdapat di desa Pantai Tinjau yaitu70,03\% setiap tahun.

\section{KESIMPULAN DAN SARAN Kesimpulan}

1. Rata-Rata pendapatan usahatani nilam yang diterima oleh petani adalah sebesar Rp.32.139.299 per tahun.
2. Rata-Rata total pendapatan keluarga petani di lokasi penelitian adalah sebesar Rp.44.243.299 per tahun.

3. Besarnya kontribusi dari usahatani nilam terhadap total pendapatan keluarga petani di Kecamatan Sekerak adalah sebesar 72,13\%. Hal ini menunjukkan bahwa usahatani nilam merupakan sumber pendapatan yang memberikan kontribusi yang tinggi. Hasil perhitungan analisis tingkat kontribusi pendapatan usahatani nilam terhadap pendapatan keluarga petani diperoleh angka $72,13 \%$, dengan kategori kontribusi tinggi karena tingkat kontribusi lebih besar dari $50 \%$ atau $72,13 \%>50 \%$. 


\section{Saran}

1. Petani sebaiknya dapat memaksimalkan usahatani nilam selain dari usaha yang lainnya.

2. Pemerintah hendaknya memberikan perhatian yang lebih diwujudkan dengan memberikan penyuluhan mengenai usahatani nilam atau memberikan bantuan berupa modal untuk berusahatani nilam

3. Perlunya pengetahuan dan keterampilan petani untuk semakin ditingkatkan terutama dalam penerapan teknologi baru yangdapat digunakan pada usahatani nilam.

\section{Daftar Pustaka}

Albar, M. 2016. Kontribusi Pendapatan Tenaga Kerja Wanita Pada Usaha Pembuatan Tempe Terhadap Pendapatan Keluarga (Studi Kasus: Kelurahan Tanjung Sari, Kecamatan Medan

Selayang).http://balitbang.pemkomeda n.go.id/tinymcpuk/gambar/file/Achma d\%20Albar.pdf. Diakses tanggal 8 agustus 2017.

Aminah, S. 2016. Analisis Pendapatan Usahatani Cabai Merah (Capsicum annum, L) dan Kontribusi Terhadap Total Pendapatan Petani di Kecamatan Idi Tunong Kabupaten Aceh Timur. Skripsi Jurusan Agribisnis Fakultas Pertanian Universitas Samudra, Aceh.

BPP Kecamatan Sekerak, 2016. Data Potensi Wilayah. BPP Sekerak : Aceh Tamiang.

Guritno, T. 1992. Kamus Ekonomi. Erlangga. Jakarta.

Hafsah, M. 2004. Prospek Bisnis Ubi jalar. Pustaka Sinar Harapan. Jakarta.

Hanum, C. 2008. Teknik Budidaya Tanaman.DPSMK.Depdiknas

Hidayatullah, A. 2011. Kontribusi Usahatani Jagung Terhadap Pendapatan Petani di Desa Pulai Damar Kecamatan Banjang Kabupaten Hulu Sungai Utara. Media Sains. Banjarmasin.

Kardinan, A. 2005. Tanaman Penghasil Minyak Atsiri Komoditas Wangi Penuh Potensi.Cetakan I. Agro Media Pustaka. Jakarta.

Kasim, K dan Sirajuddin, N. 2008. Peranan Usaha Wanita Peternak Itik Terhadap
Pendapatan Keluarga (Studi Kasus di Kelurahan Manisa Kecamatan Baranti Kabupaten Sidrap). Fakultas Peternakan Universitas Hasanuddin, Makassar.

Maulana, R. 2017. Kontribusi Usahatani Madu Sialang Terhadap Pendapatan Keluarga Petani (Studi Kasus Di Desa Gunung Sahilan Kecamatan Gunung Sahilan Kabupaten Kampar .https:// jom.unri.ac.id/index.php/JOMFEKON /article/viewFile/12992/1264. Diakses tanggal 8 Agustus 2017.

Mubyarto, 1998. Pemberdayaan Ekonomi Rakyat. Aditya Media.Jakarta.

Nazir, M. 2005. Metode Penelitian. Ghalia Indonesia, Jakarta.

Rahardja, M. 2006. Teori Ekonomi Mikro. LP Fakultas Ekonomi Universitas Indonesia. Jakarta.

Rahim, A. dan Diah R. D. H. 2007. Pengantar, Teori, dan Kasus Ekonomika Pertanian. Penebar Swadaya. Jakarta.

Reksohadiprodjo, Sukanto. 2002, Perencanaan dan Pengawasan Produksi. BPFE, Yogyakarta.

Santoso, H.B. 1990. Bertanam Nilam Bahan Industri Kanisius.Yogyakarta.

Saragih, B. 2002. Sistem dan Usaha Agribisnis. Institut Pertanian Bogor. Bogor.

Soekartawi, 2002. Prinsip Dasar Manajemen Pemasaran Hasil Pertanian Teori dan Aplikasi. Rajawali press. Jakarta.

Subroto, T. 2009. Budidaya dan Penyulingan Minyak Nilam. Pribumi Mekar. Bandung.

Sudarman, A. 2004. Teori Ekonomi Mikro. BPFE UGM. Yogyakarta.

Sudaryani, T. dan E. Sugiharti, 1999. Budidaya dan Penyulingan Nilam. Penebar Swadaya, Jakarta.

Sudremi. Y. 2007. Pengetahuan Sosial Ekonomi. Bumi Aksara. Jakarta.

Sugiyono. 2008. Metode Penelitian Bisnis. Alfabeta, Bandung.

Suratiyah, K. 2009. Ilmu Usahatani. Penebar Swadaya. Jakarta.

Suryani,2014.ManajemenAgribisnis. Aswaja, Yogyakarta.

Trianggana, Oktora. 2012. Kontribusi Pengelolaan Hutan Rakyat Terhadap Pendapatan Rumah Tangga Dan 
Analisis Kelayakan Usaha Hutan Rakyat (Studi di Desa Babakanreuma,

Kecamatan Sindangagung, Kabupaten

Kuningan, Propinsi Jawa Barat)

Departemen Manajemen Hutan
Fakultas Kehutanan Institut Pertanian

Bogor. Tidak dipublikasikan.

Wiratha, 2006. Metodelogi Penelitian Sosial Ekonomi, Andi. Yogyakarta 